\title{
1 \\ Court Records, Archives and Citizenship
}

Kim Rubenstein and Andrew Henderson

\section{Introduction}

The Federal Court of Australia performs a fundamentally important role within Australia's democratic system. Since its commencement in 1977, it has served as a site for the disputation, negotiation and resolution of issues centrally important to Australian society. It does so in the context of a constitutional system affirming the separation of powers and the rule of law, as well as providing individuals an avenue to preserve and enforce their rights, and navigate the boundaries of the powers of the state. As a 'court of record', the records of its proceedings constitute a permanent and incontrovertible record of those events. In that context, its records, gathered both through the internal workings of the court and through the cases that come before it, contain a narrative shaping our contemporary understanding of the rights of the individual and the role of the state. In many ways, this is a record of the evolution of Australian citizenship.

Although originally invested with a similar jurisdiction to the High Court, ${ }^{1}$ over those 40 years, the Federal Court has experienced successive reforms to its jurisdiction in a diverse array of legal frameworks, including

1 Judiciary Act 1903 (Cth) s 39B. 
the review of government action; ${ }^{2}$ access to government information; ${ }^{3}$ the regulation of corporations; ${ }^{4}$ the control of personal information; ${ }^{5}$ Indigenous ownership of land; ${ }^{6}$ migration; ${ }^{7}$ and national security. ${ }^{8}$ This has seen the Federal Court accumulate a significant jurisdiction concerning important aspects of those disputations, negotiations and resolutions of issues central to the evolution of the Australian community.

However, despite those transformations in the Federal Court itself and the important position it holds in our democratic system, accessing its records remains bound by traditional ideas of court files. Unlike bureaucratic and administrative records of government, access to which has been uniformly administered by the National Archives of Australia (NAA) under the Archives Act 1983 (Cth) ('Archives Act'), the application of the doctrine of separation of powers embodied within the Australian Constitution has meant that the management of Commonwealth courts' records of proceedings are administered by the courts themselves. ${ }^{9}$ Therefore, access to records of proceedings is inconsistent between the executive and legislative arms of government on the one hand, and the judiciary on the other.

Current access arrangements for the public, at least for court records over 20 years old, are also somewhat inconsistent. Although records of proceedings are not subject to the Archives Act, ${ }^{10}$ it does not mean that some of the materials that might currently be unavailable from the Federal Court are in fact unavailable from NAA. Within the records held by NAA exists agencies' own records of litigation, including affidavits, copies of

2 Administrative Decisions (Judicial Review) Act 1977 (Cth) ('Administrative Decisions (Judicial Review) Act').

3 Freedom of Information Act 1982 (Cth).

4 Michael Whincop, 'The National Scheme for Corporations and the Referral of Powers: A Sceptical View' (2001) 12(4) Public Law Review 263; Cheryl Saunders, 'A New Direction for Intergovernmental Arrangements' (2001) 12(1) Public Law Review 274.

5 Privacy Act 1988 (Cth).

$6 \quad$ Native Title Act 1993 (Cth) ('Native Title Act').

7 Sigrid Baringhorst, 'Policies of Backlash: Recent Shifts in Australian Migration Policy' (2004)

6(2) Journal of Comparative Policy Analysis: Research and Practice 131.

8 George Williams, 'A Decade of Australian anti-Terror Laws' (2011) 35 Melbourne University Law Review 1136; Paul Fairall and Wendy Lacey, 'Preventative Detention and Control Orders under Federal Law: The Case for a Bill of Rights' (2007) 31 Melbourne University Law Review 1072.

9 Archives Act s 19.

10 Ibid. 
exhibits and submissions that would be unavailable from the Federal Court. ${ }^{11}$ Nevertheless, this material is presumptively publicly available under the Archives Act. The reason for the inconsistency is not clear.

This inconsistency sits uncomfortably with ideas about open justice and does not sufficiently take into account the Federal Court's role in Australia's democratic framework beyond its role in determining disputes between the parties before it. The current approach of the Federal Court to its records, to its 'archive', we argue, represents and perpetuates the position of citizens as unequal 'subjects' and limits access to this rich and unique set of materials. It also limits society's capacity to better describe and understand its own history of how citizenship has been shaped in Australia, both broadly and through the Federal Court's work.

\section{The Federal Court and Australian Citizenship}

As Justice Susan Kenny explains, ${ }^{12}$ the origins of the Federal Court are often identified in the proceedings of the Australian Legal Convention in 1963. In a paper to the convention, Maurice Byers and Paul Toose argued for the creation of a new 'federal court'. The new court would be inferior to the High Court of Australia but vested with jurisdiction to hear and determine matters both in its original and appellate jurisdiction arising under Commonwealth law. ${ }^{13}$ In the convention proceedings that followed, the Commonwealth Solicitor-General announced that the Attorney-General, Garfield Barwick, had been given 'authority [by Cabinet] to design a new federal court. ${ }^{14}$ However, as research conducted by the Court as Archive Project demonstrates, the convention was neither the first nor the last word on the new court. The project's research also further reveals and affirms Justice Kenny's observations on the development of an 'Australian national identity' as a driver for the creation of the Federal Court.

11 See, for example, the records of proceedings in Law $v$ Repatriation Commission (1980) 29 ALR 64 and Repatriation Commission v Law (1980) 31 ALR 140 contained in National Archives of Australia (NAA): A1209, 1980/558 PART 1 and NAA: A12930, 639.

12 Susan Kenny, 'Federal Courts and Australian National Identity' (2015) 38(3) Melbourne University Law Review 996; see also Michael Black, 'The Federal Court of Australia: The First 30 Years-A Survey on the Occasion of Two Anniversaries' (2007) 31 Melbourne University Law Review 1017.

13 Maurice Byers and Paul Toose, 'The Necessity for a New Federal Court (A Survey of the Federal Court System in Australia)' (1963) 36 Australian Law Journal 308.

14 Ibid 325. 
Moreover, as Ann Genovese notes in her chapter in this collection, the first references to a new federal court appeared in 1959 in parliamentary debate on the territories and family law. Barwick had first proposed the establishment of a 'new federal court' to Cabinet in 1962, two months before the convention, noting that it was something that he had been working on 'for some time. ${ }^{15}$ Although the Solicitor-General's statement to the convention was expressed in unconditional terms, the Prime Minister's own department and the Cabinet were less enthusiastic. The breadth of the new court's role led the Prime Minister's Department to note on the submission that it went 'too far, too soon' and instead recommended examination by a committee. ${ }^{16}$ Barwick's Cabinet colleagues 'noted' (rather than agreed to) the submission and authorised the Attorney-General to prepare draft legislation on conditions, including that all Ministers reserved 'all rights to argue for or against the proposal' (emphasis added). ${ }^{17}$

Despite the laudatory announcement of the creation of a new court, at least within legal circles, the progress developing legislation to establish the new court following its first appearance in Cabinet was fitful. The proposal was prone to ongoing revision, particularly around the establishment of a 'big court' (superseding other Commonwealth courts and sitting continuously in capital cities) or a 'small court' (a 'peripatetic' court with a much smaller jurisdiction $)^{18}$ and competing priorities. ${ }^{19} \mathrm{With}$ successive general elections, responsibility for advancing the proposal also transferred between five Attorneys-General and a series of public servants, some of whom pressed enthusiastically for the creation of a new court, ${ }^{20}$

15 The Federal Judicature—Proposed New Court—Submission 461, Minute 581, NAA: A5819, VOLUME 12/AGENDUM 461. Interestingly, Byers and Toose, who would subsequently advocate for the new court at the Convention that followed, appear to have provided advice to Barwick in preparing his Cabinet Submission; see NAA: A432, 1961/2132 Part 1.

16 NAA: A5619, C430.

17 NAA: A5819, VOLUME 12/AGENDUM 461. Barwick appears to have argued later that he had never agreed to those conditions (see NAA: A4940, C3706). In an article published after the Cabinet decision in the Federal Law Review, Barwick maintained that the new court should assume responsibility for industrial relations and bankruptcy, contrary to Cabinet's 'authority'; see Garfield Barwick, 'The Australian Judicial System: The Proposed New Federal Superior Court' (1964) 1(1) Federal Law Review 1. Barwick's interpretation of the Cabinet decision might also explain the question mark in the margin of a departmental memorandum to the Attorney-General repeating the condition (see HT Bennett, 'Federal Superior Court: General Observations', NAA: A432, 1961/2132 Part 1).

18 For a discussion of the comparative elements of a 'big court' and a 'small court' model, see Bennett, above $\mathrm{n} 17$ and Barwick, above n 17.

19 See, for example, Commonwealth, Parliamentary Debates, House of Representatives, 29 October 1964, 2642 (William Snedden, Attorney-General) and 'Extract from Minutes of Meeting of Executive of the Law Council of Australia, Canberra, March 1965', NAA: A432, 1961/2132 Part 1.

20 See, for example, Letter from Attorney-General to Minister for Housing, Health and Immigration, 2 January 1969, NAA: A432; 1961/2132 Part 8. 
while others recommended its abandonment. ${ }^{21}$ The withdrawal of support for a new court by its original architect, Garfield Barwick, now Chief Justice of the High Court, also hung heavily over the proposal's success. ${ }^{22}$

However, these skirmishes over the form of the new court, and the on-and-off nature of its development, conceal the development of the consistent line of argument running through all discussions about the motivations for its establishment: the development of a more coherent body of 'Australian' (rather than state-based) jurisprudence driven by the formation of a national identity. For example, in their presentation to the convention, Byers and Toose noted that:

There is no longer a strong State sentiment amongst members of the public. Two World Wars, the financial crisis of the depression, uniform tax and Australia becoming a fully independent nation with its own ambassadors \&c [sic] and a member of the United Nations have all helped to make citizens regard themselves as Australians rather than as belonging to any particular State. ${ }^{23}$

Barwick was more prosaic but nevertheless clear in his argument for a new court to administer the 'distinctive and separate character' of Commonwealth law. He also saw the new court's role as indirectly developing an Australian jurisprudence by taking on part of the workload of the High Court, which then would be able to 'concentrate on, and adequately perform, [its] primary responsibilities as interpreter of the Constitution and ultimate national court of appeal'. ${ }^{24} \mathrm{~A}$ similar argument was made by then Solicitor-General Anthony Mason in his briefing to Attorney-General Nigel Bowen some three years later ${ }^{25}$ and, ultimately, by Attorney-General Ellicott in his submission to Cabinet ${ }^{26}$ and the House ${ }^{27}$ on the eventual introduction of what would become the Federal Court Act 1976 (Cth) ('Federal Court Act').

21 'The Federal Judicature: Proposed Commonwealth Superior Court', Submission no. 366, NAA: A5869, 366.

22 References to the withdrawal of Barwick's support for a new court is recorded at various points throughout archived materials and eventually makes its way to Cabinet (see, for example, ibid and the collected materials in NAA: A432, 1961/2132 Part 9). However, the authors were never able to find a copy of the letter itself.

23 Byers and Toose, above n 13, 313.

24 Barwick, above n 17, 9.

25 See, for example, Anthony Mason, 'A New Federal Court', 10 January 1967, NAA: A432, $1961 / 2132$ Part 5.

26 'Federal Causes and Appeals Court: Transfer of High Court Jurisdiction to State Courts', Submission no 303, NAA: A10756, LC445 PART 1.

27 Commonwealth, Parliamentary Debates, House of Representatives, 21 October 1976, 2213

(Robert Ellicott, Attorney-General). 


\section{Evolution of Australian Citizenship}

The description above reminds us that the Federal Court, in fulfilling its constitutional role, was intended to play a significant part in implementing basic concepts of national identity and citizenship in a democratic society. Moreover, the Federal Court is one of the democratic theatres in which the individual engages, disputes and negotiates with the executive arm of government, often referred to as the state.

Thinking in these terms takes us back to the core concept of the 'rule of law' in a democratic society-that those who exercise power on behalf of the state are governed by the rule of law in the same way that the individual is bound by law. ${ }^{28}$ In that sense, there is an equality to the relationship in that both the state and the individual are governed by the law. This concept is also relevant to the way Australian citizenship as a status is different to the former 'British subject' status. The evolution from being a 'subject' to being a 'citizen' in Australia involves Australia's changing relationship with the United Kingdom (UK) and the changing conception of the proper exercise of power of the state in relation to its citizens.

In 1901, when propertied, white, male Australians-those bestowed with formal, active voting rights-came together to write the Constitution, there was a democratic element to its formation. The participants were elected directly to the constitutional conventions established to draft the Australian Constitution, rather than drawing from the existing representative colonial parliaments. For that reason, those conventions were known as the 'People's convention'. ${ }^{29}$ That women and Indigenous Australians were not part of the people underlines an imbalance of power from the nation's inception. ${ }^{30}$

This is not to discount the voice of the women who were campaigning for the vote and who, as active citizens, ensured that s 41 of the Constitution guaranteed that those who already had the right to vote in the colonies would be able to vote in a new Commonwealth of Australia's federal

28 A commitment to the rule of law is also seen by the court in the privative clause cases including Plaintiff S157/2002v Commonwealth (2003) 211 CLR 476.

29 The full records of these Conventions have now been scanned and are available online, see <https://www.aph.gov.au/About_Parliament/Senate/Powers_practice_n_procedures/Records_of_ the_Australasian_Federal_Conventions_of_the_1890s $>$.

30 See Deborah Cass and Kim Rubenstein, 'Representation/s of Women in the Australian Constitutional System' (1995) 3(48) Adelaide Law Review 3. 
elections. ${ }^{31}$ This included Indigenous and white women in South Australia who had the vote at that time and, by the time of federation, white women in Western Australia, too. Indigenous South Australian women would later lose their right to vote when the Commonwealth Electoral Act 1902 (Cth), which introduced the franchise for women in federal elections, specifically excluded Indigenous people. ${ }^{32}$ The beliefs around people's equality, or lack thereof, influenced the balance of power within society at that time. Indeed, it was not until 1962 that Indigenous Australians' right to vote was passed into the Commonwealth Electoral Act 1918 (Cth). ${ }^{33}$

Formal citizenship status, which Indigenous Australians had by their birth in Australia, ${ }^{34}$ as did women, did not mean they had substantive citizenship rights. ${ }^{35}$ The 1967 referendum did not correct formal citizenship, which Indigenous Australians held, but, importantly, as the Uluru Statement from the Heart identified, ${ }^{36}$ led to them being counted. ${ }^{37}$ Indeed, formal legal membership status in 1901 was not Australian citizenship, which did not exist at that time, but rather was British subject status. A significant aspect of identity that influenced the compact of federal membership in Australia in 1901 was that the white male drafters saw themselves as British subjects, and not as Australian citizens. They did not seek to break their ties with empire at federation. In creating an Australian Commonwealth, they were establishing a compact that refigured the exercise of power in the Australian territory of the Empire between a central governing body (a federal government) and the continuing colonies (the states). Among other things, the male framers wanted to bolster their collective power to exclude immigrants (including non-white British subjects) and to create a uniformity of approach to questions of interstate trade. ${ }^{38}$

31 Section 41 states: 'No adult person who has or acquires a right to vote at elections for the more numerous House of the Parliament of a State shall, while the right continues, be prevented by any law of the Commonwealth from voting at elections for either House of the Parliament of the Commonwealth'. 32 For an explanation of $s 41$ and the involvement of the South Australian women's role in its evolution, see Elisa Arcioni and Kim Rubenstein, ' $R$ v Pearson; Ex parte Sipka [1983] HCA 6: Feminism and the Franchise' in Francesca Bartlett, Trish Luker and Rosemary Hunter (eds), Australian Feminist Judgments: Righting and Rewriting Law (Hart Publishing, 2014) 55.

33 See Kim Rubenstein, Australian Citizenship Law (Thomson Reuters, $2^{\text {nd }}$ ed, 2017) [2.220] and [6.190].

34 See discussion about citizenship by birth in ibid [3.50], [4.50], [4.70], [4.200], [4.250], [7.8].

35 Ibid [1.20].

36 See Uluru Statement from the Heart (26 May 2017) <https:/www.referendumcouncil.org.au/ sites/default/files/2017-05/Uluru_Statement_From_The_Heart_0.PDF>.

37 See some excellent material online about the 1967 Referendum at <https://www.nla.gov.au/ research-guides/the-1967-referendum>.

38 See Helen Irving, 'To Constitute a Nation: A Cultural History of Australia's Constitution' in Anthony Blackshield and George Williams (eds), Australian Constitutional Law and Theory, Commentary and Materials (Cambridge University Press, $6^{\text {th }}$ ed, 1999). 
Ultimately, this led to a clear decision not to include a formal legal concept of Australian citizenship in the Australian Constitution. ${ }^{39}$ All individuals born in Australia were British subjects by birth until the introduction of the Australian Citizenship Act 1948 (Cth) on 26 January 1949. ${ }^{40}$ When that Act came into effect, Australian citizenship status arose automatically by birth in Australia ${ }^{41}$ and sat alongside the continuing British subject status. Australian citizens were both Australian citizens and British subjects until $1987 .{ }^{42}$

When British subject status was repealed, and Australians became solely Australian citizens in 1987, it represented an important shift. This was not only about a change around the relationship between Australia and the UK that had consequences for British subjects residing in Australia who were not Australian citizens, ${ }^{43}$ but it reflected a change to Australian conceptions of sovereignty. It was also a time when the Australian executive acknowledged that no matter which country a person came from, they had equal access to applying for Australian citizenship. ${ }^{44}$

The earlier position of being a 'subject' in a colonial, monarchical setting represented an imbalance of power that underpins British subject status compared to Australian citizenship. Being a British subject was at its core a relationship between the Crown and the subject where the individual was subjected to the power of the Crown or the state. This was not only in the sense that any form of power (whether called the Crown or the executive) has a 'subject' to which the power extends, but also because the Crown was entitled, by its own divine foundations, to control the subject. This lies in British subject status's feudal origins, where the concepts of allegiance were tied up, as Peter Spiro explains:

39 See Kim Rubenstein, 'Citizenship and the Constitutional Convention Debates: A Mere Legal Inference' (1997) 25(2) Federal Law Review 295.

40 When first introduced, it was called the Nationality and Citizenship Act 1948 (Cth) and was renamed the Australian Citizenship Act 1948 (Cth) in 1973. See Rubenstein, above n 33, [4.130].

41 There are various ways to become an Australian citizen: by birth, descent and naturalisation (now known as conferral). See Rubenstein, above n 33, [4.200].

42 See the discussions about British subject status in ibid [3.120], [4.140], [4.170], [4.180] and [4.190].

43 This included British subjects being able to be deported under the Migration Act 1958 (Cth). See also Kim Rubenstein and Niamh Lenagh Maguire, 'Citizenship Law' in Ian Freckleton and Hugh Selby (eds), Appealing to the Future: Michael Kirby and His Legacy (Thomson Reuters, 2009) 105.

44 See Rubenstein, above n 33, [4.190]. 
In a medieval world, [where] individuals were identified not so much by primitive national affiliations as by personal allegiances tied to natural law. The notion of personal allegiances persisted as Europe divided into distinct territorial units, each ruled by an individual sovereign. So conceived, early models of nationality and citizenship worked from the putatively personal relationship between the individual and the sovereign. ${ }^{45}$

The Crown could ultimately determine who it chose to protect and upon whom to bestow its benevolence. This translated into the common law identifying all people born within the Crown's dominions as being subject to the Crown's power and benevolence. This was the result of the relationship in feudalism between the individual and the soil upon which she lived. ${ }^{46}$ In terms of the subject-sovereign relationship, jus soli was justified on the grounds that the child was upon birth indebted to the King for her protection. ${ }^{47}$ While subjects gained some benefits from that relationship (although not uniformly, as Indigenous and Chinese Australians' and women's experiences affirm), ${ }^{48}$ there was a fundamental inequality in the relationship.

Becoming solely Australian citizens signified, linguistically, a move away from that foundational inequality. While Australia still had a Queen as Head of State, she became the Queen of Australia, and this move away from British subject status also changed the concept of power between the executive branch of government - those governing and making the law-and the people - those subject to the law. Citizenship, as opposed to 'subjectivity', philosophically and legally represents an equality between those exercising power and those subject to that power. In Australia, this also represented a move with parallels in timing to becoming a multicultural society. From that time on, all individuals, whether part of the Commonwealth or not, would have equal access to citizenship, compared to the earlier preference for British (white) subjects.

These changes are integral to the development of a democratic understanding of citizenship. It parallels a commitment to the principle that those exercising power are subject to the law in the same way that the citizenry is subject to the law. All citizens-those governing and those

45 See Peter Spiro, 'Dual Nationality and the Meaning of Citizenship' (1997) 46 Emory Law Journal 1411, 1419.

46 Ibid, citing WE Hall, International Law (Clarendon Press, $7^{\text {th }}$ ed, 1917), 234.

47 Ibid, citing William Blackstone, Commentaries on the Laws of England (Clarendon Press, 1768) vol 1, 369-70.

48 See Peter Prince, Aliens in their Own Land (PhD thesis, The Australian National University, 2015). 
being governed - are formally equal before the law. While the story of Indigenous citizenship, even at that point, highlighted some of the flaws in translating this theory to practice, the move to Australian citizenship over British subject status was the first step towards a democratic concept of Australian citizenship.

This change also built upon the growth of the application of administrative law principles in Australia with the 'new' administrative law framework introduced in the 1970s. ${ }^{49}$ Those changes, including the introduction of freedom of information laws, the office of the Ombudsman, the creation of Administrative Appeals Tribunals and codified judicial review processes, all articulated and implemented clear controls on the exercise of executive power. Individual citizens could challenge government exercises of power, primarily in the Federal Court of Australia, and this administrative law foundation amplified this newer understanding of Australian citizenship. Just as the concept of the rule of law emphasises that those who exercise power are 'subject to the law', so too was the sole status of citizenship central to democratic understandings of citizenship and the fact that those citizens who were exercising power, the executive branch of government, were also 'subject to the law'.

It is within these 'matters', where individuals seek to challenge the exercise of executive power in the Federal Court, that we see a significant story of Australian citizenship.

\section{The Federal Court as an Archive}

The intent and history of the Federal Court is inherently linked to a narrative of national identity and is, therefore, not only a repository of legal procedure, but also an important legal, social, cultural and historical archive.

In practical terms, the traditional focus placed on the work of superior courts, like the Federal Court, is generally on their end product: judgments, orders and reasons. For the litigants, judgment represents the end the litigation, the consequence of which may be significant. The making of orders under the Administrative Decisions (Judicial Review) Act

49 See Peter Cane, Leighton McDonald and Kristen Rundle, Principles of Administrative Law (Oxford University Press, $3^{\text {rd }}$ ed, 2018). 
may represent protection from unlawful executive action. The making of orders under the Native Title Act may represent the recognition of deeply held spiritual and cultural connections to the land. For the legal profession in a common law system such as Australia's, judgment might represent a statement of what the law is, with an eye to appeal if the statement is perceived to be wrong. For the public who do not generally see courts in action, judgments provide the opportunity to critically assess the performance of the courts and judges in terms of timeliness or even the extent to which they are 'in touch' with the community. ${ }^{50}$

For the High Court, the determination of a dispute between two or more parties is the fundamental purpose of a Commonwealth court established under Chapter III of the Constitution. The High Court's jurisdiction is circumscribed by s 75 of the Constitution. A 'matter' must 'involve some right or privilege or protection given by law or the prevention, redress or punishment of some act inhibited by law'. ${ }^{51}$ In its narrowest sense, the resolution of the dispute involves 'attaching a definite legal consequence to a definite, detailed state of facts'. ${ }^{52}$

However, in common law systems reliant on precedent as both a body of law and a tool of statutory interpretation, the effects of judicial decisionmaking are not bound in space or time, but may be felt well beyond individual disputes. The resolution of a dispute and the publication of reasons may have a far-reaching effect in defining a community and its relationship with the state. ${ }^{53}$ The application of a body of law derived from principles and precedent provides continuity, consistency and certainty in individuals' relationships with one another and with the state. ${ }^{54} \mathrm{~A}$ decision may also reach back in time to either affirm or reject previous interpretations of the law or redefine legal and personal relationships. ${ }^{55}$ In a broader sense, courts play an important role in

50 Murray Gleeson, 'Out of Touch or Out of Reach?' (2006) 7 The Judicial Review 241, 241. The concept is not a new one. See, for example, the remarks of the Hon Samuel Griffith on the first sitting of the High Court reported in 'The High Court: Opening Ceremony, Distinguished Gathering', The Argus (Melbourne), 7 October 1903, 9 <http://nla.gov.au/nla.news-page333047>.

51 In Re Judiciary and Navigation Acts (1921) 29 CLR 257, 266.

52 Ruggero Aldisert, 'The Role of the Courts in Contemporary Society' (1977) 38(3) University of Pittsburgh Law Review 438, 439.

53 Anthony Mason, 'The Use and Abuse of Precedent' (1988) 4 Australian Bar Review 93. See also traditional ideas of the common law representing common custom and usage in Rupert Cross and JW Harris, Precedent in English Law (Clarendon Press, 1991), 36-7.

54 Mason, above n 53. See also Mirehouse v Rennell (1833) 1 Cl \& F 527, 546.

55 Oscar G Chase, "Supreme" Courts and the Imagination of the Real' (2015) 518 New York University Public Law and Legal Theory Working Papers 14. 
affirming the community's understanding of ideas of identity, belonging, citizenship and rights. Through their reasons for decision, courts reinforce the acceptance of certain ideas while rejecting or disapproving of others. ${ }^{56}$

Traditional ideas about archives saw their contents as embodying a form of impartial 'truth' or 'evidence' derived from ideas about providence. ${ }^{57}$ Postmodern critiques of this traditional construction have argued that the selection, retention and preservation of records in state-run archival institutions means that a particular view of the state is created and preserved..$^{58}$ There is a strong parallel in this thinking between archives and reasons for decision. As a pronouncement of an impartial decisionmaker whose decisions are enforced by the state, reasons represent a state-sanctioned account of the parties' relationship. As the product of an adversarial system, reasons are perceived to incorporate the distilled 'truth' of the matter. As a matter of providence, the pedigree of reasons is arguably impeccable. From a postmodern perspective, as a court established by Commonwealth legislation, the Federal Court's decisions are explicitly endowed with state-sanctioned significance. Whereas archival institutions might be seen to exercise a type of 'soft' power in terms of defining the community, the precedential value of judicial decision-making means that courts are expected to engage actively in defining acceptable behaviour. ${ }^{59}$

So why not stop there and accept the extent of the Federal Court's archives as currently understood? Shouldn't its orders and reasons for decisions meet the needs of all their potential users, including historical researchers? We argue that they represent the end point in litigation. Although the reasons for decision may provide a summary of the evidence and the proceedings at trial, they are just a summary. The summary is limited to only those facts that have been 'ascertained' by the court and identified as legally significant. ${ }^{60}$ In effect, the reasons present a narrow set of facts viewed through a particular lens of relevance and legal principle and rendered for a particular purpose. ${ }^{61}$

56 Ibid.

57 Francis X Blouin Jr and William G Rosenberg, Processing the Past: Contesting Authority in History and the Archives (Oxford University Press, 2011) 232; Brien Brothman, 'Afterglow: Conceptions of Record and Evidence in Archival Discourse' (2002) 2 Archival Science 311.

58 Joan Schwartz and Terry Cook, 'Archives, Records and Power: The Making of Modern Memory' (2002) 2 Archival Science 1; Blouin Jr and Rosenberg, above n 57, 151

$59 \mathrm{~J}$ Willard Hurst, 'Legal Elements in United States History' in Donald Fleming and Bernard Bailyn (eds), Perspectives in American History (Little Brown Books, 1971) vol 2, 3.

60 Michael McHugh, 'Judicial Method' (1999) 73 Australian Law Journal 37, 37.

61 Clifford Geertz, Local Knowledge: Further Essays in Interpretive Anthropology (Basic Books, 2008) 173. 
A reliance on reasons alone is the study of precedent that is often referred to as 'lawyers' history'. ${ }^{62}$ To the extent that the decision reflects or affects the wider community, it tells only part of the story. Materials presented by the parties provide both the canvas and the frame for the decision. They provide the foundation for the decision and describe the broader context within which the decision is made. It is here that court records arguably hold more value to the researcher as a companion, or even contradictor, to state-run archives. As noted above, postmodern critiques of archives argue that to the extent archival institutions are created by, and contain records of, the state, they give primacy to a representation of the community constructed by the state and exclude contradictory voices. ${ }^{63}$ In the context of the individual's relationship with the state, it might exclude or explicitly devalue or discredit voices of protest.

Within the court's own records, contradictory voices are not just heard but are explicitly required. The evidence and other materials submitted to the court are representative of the voices of those who submitted them. They do not contain just one version of a series of events but may contain two or more or multiple stories told in different ways and from different perspectives. Statements of claim and collected evidence describe the litigants' relationship and, to the extent that the eventual decision will affect that relationship in the future, their hopes or expectations of what it should be. Within these documentary accounts are cultural and social assumptions-both explicit and implicit-that provide insight into those relationships. ${ }^{64}$ Perhaps even more crucially, the requirement in Commonwealth courts of a 'matter' means that these are snapshots of those assumptions in conflict and contested ideas about what is acceptable. A more complete archive begins to explain 'not only what went on in the law's formal processes, but what were the full actual effects that law and the life environing the law had on each other'. ${ }^{65}$

62 Kinvin Wroth, 'Documents of the Colonial Conflict: Part I-Sources for the Legal History of the American Revolution' (1976) 69 Law Librarians Journal 277, 277.

63 Brothman, above n 57; Blouin Jr and Rosenberg, above n 57; Jacques Derrida, Archive Fever: A Freudian Impression (Eric Prenowitz trans, University of Chicago Press, 1996); Nancy Cochran, Andrew Gordon and Merton Krause, 'Proactive Records: Reflections on the Village Watchman' (1980) 2(1) Science Communication 5; Ciaran B Trace, 'What is Recorded is Never Simply "What Happened": Record Keeping in Modern Organizational Culture' (2002) 2 Archival Science 137. See also s 2A of the Archives Act and the definition of 'archival resources of the Commonwealth'.

64 Michael Hindus, Theodore Hammett and Barbara Hobson, The Files of the Massachusetts Superior Court, 1859-1959: An Analysis and a Plan for Action (GK Hall \& Company, 1979) 3.

65 Hurst, above n 59, 3. 
The Federal Court's collected materials, therefore, allow the researcher to move beyond 'lawyers' history' and state-focused constructs of community. The voices of litigants, while advocates in their own cause, are inherently authentic and in that sense true to themselves. In our understanding of an individual's relationship with the state and with each other, in an understanding of this story of Australian citizenship, those records provide a time capsule of the assumptions, ideas and the conflicts between the state and its citizenry. To the extent that the law also reaches both forward and backward, these firsthand accounts also serve to explain how current relationships have evolved.

This concept of superior courts as archives is further strengthened by the historical development of the concept of 'courts of record'ongoing, permanent and inconvertible records of the disputes that come before them.

\section{Public Access to the Courts and Court Records}

At its establishment, the Federal Court was created as a 'superior court of record'. ${ }^{66}$ The concept of 'courts of record' is inherently linked with the origins of an Anglo-Australian legal system and defines the status of a court within a legal hierarchy. However, what constitutes 'the record', and the manner in which it is to be kept, remains largely undefined. It is determined by context. ${ }^{67}$ In the best traditions of the common law, what is 'the record' for the purposes of public access has therefore been determined by tradition and practice adopted as precedent. The Federal Court, as with other courts, has adopted a role as custodian and curator of records confined to traditional ideas of access.

The practice of courts creating and maintaining records of proceedings developed in or about the $13^{\text {th }}$ century. ${ }^{68}$ Until that time, records of what had happened before the justices were largely oral. Over time, what were originally referred to as rolls developed from notes to aid memory to more

66 Federal Court of Australia Act 1976 (Cth) s 5.

67 For example, see the discussion of what constitutes an inferior court's record for the purposes of a writ of certiorari in Craig $v$ South Australia (1995) 184 CLR 163.

68 SE Thorne, 'Courts of Record and Sir Edward Coke' (1937) 2(1) The University of Toronto Law Journal 24, 28. 
complete records containing detailed statements of what happened in proceedings. According to some accounts of the development of English courts, those holding records therefore become 'courts of record' and different from those that did not. ${ }^{69}$ From this relatively simply distinction, courts of record have accumulated further distinguishing characteristics, including the power to fine, imprison and punish contempt. ${ }^{70}$ In Australia, questions about whether a court is one 'of record' have generally been resolved by the legislation establishing it. ${ }^{71}$

The history of proposals to establish what is now the Federal Court is generally silent on its status, other than it was always intended to be 'superior'. ${ }^{72}$ However, it is implicit throughout the development of proposals for the Federal Court over the following decade that it should at least have the status equivalent to a superior court, or the state supreme courts, suggesting that it was always intended to be a court 'of record'.

\section{What is the Record?}

While a court's status may be clear, what constitutes its 'record', particularly for superior courts, remains vague. Decisions about the content of 'the record' are largely confined to administrative law and focus on the records of inferior courts, the content of which is to be determined by the court on an application for review ${ }^{73}$ or by reference to the legislation establishing the court or tribunal. ${ }^{74}$

While not determinative, these definitions set a logical minimum content for the record. As the High Court notes, it provides an account of how the matter came before the court, the contentions of the parties and the orders made - the basic information necessary to record the dispute between the parties and its resolution. In that sense, it remains tied to

69 Ibid 35. Interestingly, Thorne goes on to discuss the distinction argued for by Sir Edward Coke that only courts of record can fine and imprison and finds that there is no authority for the connection other than common lawyers' desire to 'cripple' rival courts that kept no record.

70 Enid Campbell, 'Inferior and Superior Courts of Record' (1997) 6 Journal of Judicial Administration 249, 254. For a comprehensive history of the development of these other distinctions, see also Thorne, above n 68 .

71 Campbell, above n 70, 257.

72 NAA: A432, 1961/2132 Part 1.

73 Craig v South Australia (1995) 184 CLR 163, 182 quoting Hockey v Yelland (1984) 157 CLR 124, 143; see also Kirk v Industrial Court of New South Wales (2010) 239 CLR 531, 576 and the discussion there of the Privy Council's similar conclusion in $R v$ Nat Bell Liquors [1922] 2 AC 128.

74 Kirk (2010) 239 CLR 531, 578. 
the historical purposes of the maintenance of a record, both as an aid to memory of how proceedings had been disposed and as a summary for the purposes of superior courts' supervision. ${ }^{75}$ The advent of court registries and standard forms has arguably extended the idea of the record to include the documents filed with the registry. ${ }^{76}$

This idea of records reflects a traditional procedural and precedential understanding of how or why those records are important. However, it tells us very little about their character and ignores the larger context within which written records developed. That context reveals their significance and begins to describe how issues about their access and retention might be approached.

\section{Perpetual Memorial, Incontrovertible Evidence and Status}

While the practice of keeping records began as an aid to justices, ${ }^{77}$ their evolution as detailed accounts of proceedings endowed them with a sense of permanence. Holdsworth, in his history of English law, refers to courts of record as being courts whose 'proceedings are enrolled in parchment for a perpetual memory and testimony' (emphasis added). ${ }^{78}$ The nature of the record as being perpetual was echoed by Lord Denning 20 years later, ${ }^{79}$ and by the High Court, ${ }^{80}$ which defined the records of a court with a similar sense of permanence as being the proceedings 'preserved in [the court's] archives'. ${ }^{81}$

In addition to permanence, court records were considered incontestable as to their contents. Oral records of proceedings in the King's courts were considered incontrovertible and not open to question. ${ }^{82}$ With the development of written records of proceedings, the written form was

75 The High Court's own discussion of the 'the record' in Kirk in fact begins with a reference to the role of the King's Bench in the $18^{\text {th }}$ century; Kirk (2010) 239 CLR 531, 568.

76 Baldwin \& Francis Ltd and Patents Appeal Tribunal [1959] AC 663, 688.

77 Thorne, above $\mathrm{n} 68$.

78 William Searle Holdsworth, A History of English Law (Methuen \& Co., 1924) vol 5, 157.

79 Baldwin \& Francis Ltd and Patents Appeal Tribunal [1959] AC 663, 688.

80 Lane v Morrison (2009) 239 CLR 230.

81 Ibid 243.

82 Thorne, above n 68. 
similarly incontrovertible. Further proof of the content of the record was neither required ${ }^{83}$ nor accepted: ${ }^{84}$ a position that has been enshrined in the Evidence Act 1995 (Cth) ${ }^{85}$

Taken together, these two principles-an incontrovertible record to be held in perpetuity-makes courts' records more than a procedural catalogue. They speak directly to both the status of the record itself and its custodian. For example, on the establishment of the failed Australian Military Court (AMC), the Commonwealth Government inserted amendments to the bill making the AMC 'a court of record'. Arguments to make the AMC a 'court of record' had been opposed by the Department of Defence on the basis that it was unnecessary and that the bill already provided for the new AMC to keep records. ${ }^{86}$ However, submissions on the bill recommended that regardless of whether the bill already provided for the powers of a 'court of record', the AMC should be explicitly created as one in recognition of its powers, its status and its authority. ${ }^{87}$ On the introduction of the amendment, the government noted that the amendment 'further enhance[d] the status of the AMC' ${ }^{88}$

\section{Open Justice}

While it is one thing to argue that a court's record of proceedings constitutes a permanent archive of proceedings, why should those records be available to the public? The origins of 'the record' are found in aids to the court, rather than the outside world. However, to argue that the 'the record' is a private or an exclusive collection ignores other elements of the administration of courts. In particular, the position that the conduct of proceedings is transparent and open to all (subject to limited conditions) as a fundamental guarantee of the fairness of those proceedings.

83 Ibid; Gaillard Lapsley, 'The Court, Record and Roll of the County in the Thirteenth Century' (1935) 51 Law Quarterly Review 299, 319.

84 See LexisNexis, Halsbury's Laws of Australia, (online at 25 January 2019) 195 Evidence, '3 Special Modes of Proof' [195-2310].

85 Evidence Act 1995 (Cth), s 157 (proof of civil proceedings) and s 178 (proof of criminal proceedings).

86 Department of Defence, Answers to Questions Raised to Senate References Committee on Foreign Affairs, Defence and Trade, Parliament of Australia, Inquiry into provisions of the Defence Legislation Amendment Bill 2006, 9 October 2006, 6.

87 Len Roberts-Smith, Submission No. P3 to the Senate References Committee on Foreign Affairs, Defence and Trade, Parliament of Australia, Inquiry into Provisions of the Defence Legislation Amendment Bill 2006, 19 September 2006, [9].

88 Supplementary Explanatory Memorandum, Defence Legislation Amendment Bill 2006 (Cth), [13]. 
The commitment to courts operating in public is most immediately recognisable in the traditional adage that "justice should not only be done, but should manifestly and undoubtedly be seen to be done' ${ }^{89}$ The origins of the idea are not clear, either arising out of the practices of early courts, ${ }^{90}$ a corollary of courts being public events ${ }^{11}$ or 'more or less accidental' as a necessary part of criminal jury trials. ${ }^{92}$ However, since at least the $17^{\text {th }}$ century, ${ }^{93}$ it has been accepted and entrenched in English law. It is also now seen to be closely tied to the principles of a fair trial, judicial impartiality, judicial independence and the maintenance of public confidence in the courts. ${ }^{94}$

As Ernst Willheim outlines in his chapter in this collection, the concept of 'open justice' is acknowledged in Australia and internationally as a fundamental element of the judicial process, consistently acknowledged in both precedent and extrajudicially by members of the High Court.

The judicial and academic discussion of open justice has mainly constructed the concept around direct, unmediated access to courts in person. However, this 'face-to-face model' of courts' relationship with the community is inconsistent with current practice, is outdated and increasingly problematic. With the advent of more extensive media and more universally consistent levels of literacy, it has been argued that the traditional model of the public visiting the courts to see justice 'being done' is outmoded. ${ }^{5}$

89 This statement comes from $R v$ Sussex Justices; Ex parte McCarthy [1924] 1 KB 256, 259.

90 Raybos Australia Pty Ltd \& Anor v Jones (1985) 2 NSWLR 47, 51, citing P Wright, 'The Open Court: The Hallmark of Judicial Proceedings' (1947) 25 Canadian Bar Review 721.

91 Garth Nettheim, 'The Principle of Open Justice' (1984-86) 8 University of Tasmania Law Review $25,26$.

92 Ibid, citing Max Radin, 'The Right to a Public Trial' (1931-1932) 6 Temple Law Quarterly 381, 382. A similar observation is made by Chief Justice Burger in Richmond Newspapers Inc v Virginia, 448 US 555, 565 (1980), who, in turn, attributes it to William Holdsworth, A History of English Law (Little Brown Books, $3^{\text {rd }}$ ed, 1938) vol 10.

93 In Raybos (1985) 2 NSWLR 47, Kirby P identifies references to public trials as early as 1649, while Nettheim, above n 91, 27 refers to Sir Edward Coke's Institutes of the Laws of England published in 1642 .

94 Hogan v Hinch (2011) 243 CLR 506, 530.

95 Helen Gamble and Richard Mohr, 'Courts and Communities: Tensions and Accommodations' in Richard Mohr and Sandra Lloyd (eds), Delivering with Diversity (University of Wollongong, 1996), 7; Patrick Keyzer, 'What the Courts and the Media Can Do to Improve the Standard of Media Reporting of the Work of the Courts' (1999) 1 University of Technology Sydney Law Review 150, 152. 
Assuming for the moment that the public can attend proceedings, what is it that they are likely to hear? As has been discussed by Willheim, ${ }^{96}$ and others, ${ }^{97}$ legal proceedings in the Federal Court are now largely conducted by the exchange of written evidence, materials and submissions, almost all of which are unavailable to the public. To the extent that the principle of 'open justice' is based on the assumption that all, or a large part of, the material available to the court would be read aloud in open court, it refers to practices that are now largely defunct. Byrne J in $M c C a b e v$ British American Tobacco Australia Services Limited $^{98}$ summarised the development of civil litigation since the 1980s as:

The ensuing two decades of civil commercial litigation have witnessed the progress of this trend in the interests of increased efficiency in the trial process. The modern trial judge is confronted with substantial court books, often in electronic form, volumes of witness statements, written outlines of counsel's openings and final addresses, chronologies and photocopies of cases relied upon, most of which are to be read out of court and which, for the most part, are merely alluded to at trial. This serves to make the curial and adjudicative process less and less comprehensible to the person in the public gallery. ${ }^{99}$

The emphasis on greater efficiency in litigation has been further reinforced in the Federal Court with the introduction of amendments intended to 'bring about a cultural change in the conduct of litigation'. ${ }^{100}$ Since 2010 , the procedures applying to civil litigation must be consistent with an 'overarching purpose' of facilitating 'the just resolution of disputes according to law as quickly, inexpensively and efficiently as possible'. ${ }^{101}$ Amendments have also been introduced requiring the parties to take 'reasonable steps' to attempt to resolve the dispute before initiating proceedings. ${ }^{102}$

96 Ernst Willheim, 'Are Our Courts Truly Open?' (2002) 13 Public Law Review 191.

97 Sharon Rodrick, 'Open Justice, the Media and Avenues of Access to Documents on the Court Record' (2006) 29(3) UNSW Law Journal 90.

98 McCabe v British American Tobacco Australia Services Limited [2002] VSC 150.

99 Ibid [19].

100 Explanatory Memorandum, Access to Justice (Civil Litigation Reforms) Amendment Bill 2009 (Cth), 3.

101 Federal Court of Australia Act, s 37M. This includes an obligation on the parties to conduct litigation in accordance with the 'overarching purpose' (see s 37N). See also Cement Australia Pty Ltd v Australian Competition and Consumer Commission (2010) 187 FCR 261 for a discussion of the interpretation of the provision.

102 Civil Dispute Resolution Act 2011 (Cth), ss 6 and 7. 
These measures seeking to reduce the cost of litigation, or avoid it completely, are valuable and significant in improving access to justice. However, allied to these changes is also the active encouragement of the parties and the Federal Court to attempt to resolve issues informally or through processes that are not available to the public. ${ }^{103}$ Even for members of the public who do seek access to written materials, there is the additional burden of cost. Inspection and copying of accessible materials attract a fee, ${ }^{104}$ while parties, the public and the media must order transcripts from an external provider and pay a fee. ${ }^{105}$

\section{Conclusion: Access and Citizenship}

Restrictions on access to courts' unique store of materials reflect on all aspects of Australian citizenship: as a legal term, as a frame for thinking about the relationship between the citizen and the state, and as a way of encouraging active citizenship. This chapter has explained how our thinking about courts' archives is related to, and influenced by, the evolution of citizenship in Australia historically, from federation to the growing jurisdiction of the Federal Court of Australia. Restrictions on access to documents impacts on Australian citizenship as well as on a general understanding of the rule of law and open justice as modern expectations of the justice system.

Maintaining a narrower view of 'the archive' perpetuates a system of inequality between the citizen and the state that is now out of date. In the present context, the state determines what the citizen can see based on old ideas about courts, their proceedings and their records. It also restricts access based on a practical fiction that the public can, at any time, turn up and witness proceedings.

Given the evolving jurisdiction of the Federal Court, and changing ideas about restrictions on access based on its function as a court, maintaining a traditional view of the Federal Court's record ignores its role evolving in parallel as an archive. The Federal Court's role as a site for disputation,

103 See, for example, Federal Court of Australia, Practice Note CM 1: Case Management and the Individual Docket System, 1 August 2011; Law Council of Australia and Federal Court of Australia, Case Management Handbook (Law Council of Australia, 2014).

104 Federal Court and Federal Circuit Court Regulation 2012 (Cth), Schedule 1, Part 1, Item 123.

105 Federal Court of Australia, Access to Transcript (n.d.) Federal Court of Australia <www.fedcourt. gov.au/services/access-to-files-and-transcripts/transcript $>$. 
negotiation and resolution about rights, particularly those around the power of the executive and the role of the state, means that its records speak directly to the evolution of Australian society. The different perspectives and the process by which the state (in the broadest sense) decides what those rights and roles are, in the growing jurisdiction of the Federal Court of Australia, ultimately confirms it is part of the evolution of Australian citizenship. The citizenry must, therefore, be in a position to access materials that inform that national identity, consistent with a change in status from 'subjects' to equal 'citizens'. 
This text is taken from The Court as Archive, edited by Ann Genovese, Trish Luker and Kim Rubenstein, published 2019 by ANU Press, The Australian National University, Canberra, Australia. doi.org/10.22459/CA.2019.01 